\title{
The Inequality Story in Latin America and the Caribbean: Searching for an Explanation
}

\author{
Augusto de la Torre, Julian Messina, and Joana Silva
}

\section{Introduction}

Income inequality is a salient economic malaise in Latin America and the Caribbean, where for decades it has been higher than in any other region in the world (Williamson 2015). A growing body of literature suggests that after a long period of growing or stagnant inequality, the trajectory of household income inequality shows a visible kink around 2003 - rising during the 1990s and until about 2002, when it started to descend, a trend that was particularly steep during the boom period of 2003-2011 before flattening out during the post-2011 slowdown. This trajectory contrasts with that of Latin America and the Caribbean in previous periods or other regions in the same period (Alvaredo and Gasparini 2015; De Ferranti et al. 2004; De la Torre et al. 2014; Gasparini and Lustig 2011; López-Calva and Lustig 2010).

Although the path of household income inequality in Latin America and the Caribbean was not independent of (redistributive) social policy, this chapter argues that in the 2000s the behavior of the region's labor markets had the dominant role. In particular, pro-poor labor market dynamics led to a downward trajectory in labor income inequality that closely mirrored that of household income inequality. This is not to say that transfers to the poor and other social programs introduced or expanded during the first years of the millennium did not contribute to the trends. About one-third of the changes in household income inequality can be attributed to redistributive policies (Cord et al. 2014). This chapter is about the remaining two-thirds that correspond to the workings of the labor market. It examines the trends and discusses possible driving factors behind the historical facts.

A. de la Torre $\bullet$ J. Silva $(\bowtie)$

The World Bank, 1818 H Street NW, Mail stop I9-900, Washington, DC, USA

J. Messina

Inter-American Development Bank, 13000 New York Avenue NW, Washington, DC, USA

(C) The Author(s) 2017

L. Bértola, J. Williamson (eds.), Has Latin American Inequality

Changed Direction?, DOI 10.1007/978-3-319-44621-9_13 
An important stylized fact in Latin America and the Caribbean is that the reduction in labor income inequality was, in turn, largely driven by changes in the skill premium (as measured by the wage returns to tertiary versus primary education), which again followed a path that broadly mirrored, over the entire period, that of labor income inequality (De la Torre et al. 2014; 2015a, b). Previous empirical research on the region has linked this decreasing skill premium to several intuitive supply and demand mechanisms:

- Expanded access to education across the region's countries increased the skilled labor supply. The increased supply of skilled workers exerted downward pressure on wage inequality by decreasing the wage skill premium (Azevedo et al. 2013; Gasparini et al. 2011, Gasparini and Lustig 2011; López-Calva and Lustig 2010; Lustig et al. 2013).

- Changes in technology and international trade decreased the wage gap between skilled and unskilled workers by expanding the demand for unskilled labor relative to skilled labor (Gonzaga et al. 2006).

- Institutional factors that decreased the skill premium exerted upward pressure on wages at the bottom by rising minimum wages in Brazil (Barros et al. 2010) or enhancing unions' empowerment in Argentina (Gasparini and Cruces 2010).

This chapter adds to this growing literature by discussing the contribution of each of these factors as well as offering new hypotheses, using household survey data, ${ }^{1}$ on determinants of the evolution of the skill premium and the channels through which such determinants were transmitted.

The remainder of the chapter is organized as follows: Sect. 2 describes in detail the main stylized facts on labor inequality in Latin America and the Caribbean. Section 3 discusses the supply-side determinants (presenting some new hypotheses) and the demand-side drivers. Section 4 concludes.

\section{Stylized Facts}

\subsection{Falling Income Inequality: A Break with Recent History}

The 2000s were a period of inequality reduction in Latin America and the Caribbean. This trend contrasted sharply with the 1990s, when inequality increased in the region (Alvaredo and Gasparini 2015; De Ferranti et al. 2004; De la Torre et al. 2014; Gasparini and Lustig 2011; López-Calva and Lustig 2010; World Bank 2011a, b). Between 2002 and 2013, the Gini coefficient of household income

\footnotetext{
${ }^{1}$ Household survey data were compiled from the Socio-Economic Database for Latin America and the Caribbean (SEDLAC) of the Center for Distributive, Labor and Social Studies (CEDLAS) of the Universidad de La Plata, Argentina, and the World Bank, Washington, DC, http://sedlac.econo. unlp.edu.ar/eng/.
} 


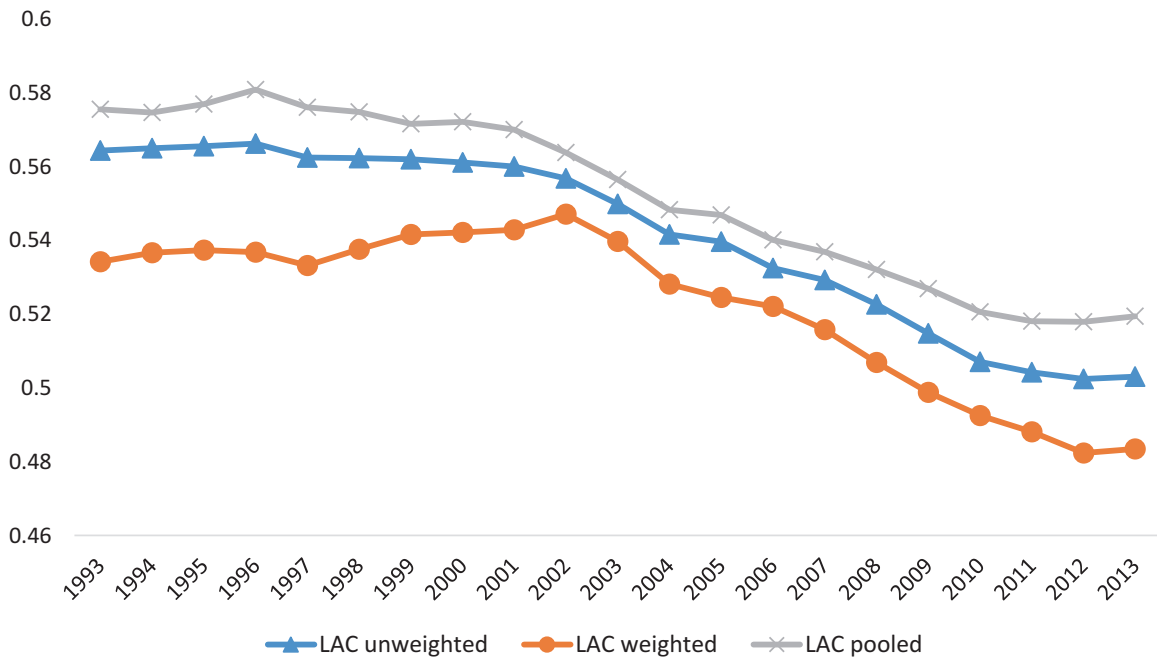

Fig. 1 Household income inequality: simple averages Gini LAC 1993-2013. Source: Based on SEDLAC (World Bank and CEDLAS). Note: LAC interpolated dataset, built using microdata for 17 countries. For more information about the interpolation see World Bank (2015). Source: Rodríguez-Castelán et al. 2016

inequality fell by 5.3 points, from 55.6 to 50.3 Gini points (Fig. 1). ${ }^{2}$ Using other inequality measures, the conclusions are the same: inequality fell strongly (Azevedo et al. 2013; Cord et al. 2014).

The Gini coefficient is the most commonly used measured of income inequality, but it is sometimes difficult to grasp its intuitive meaning. One useful way to interpret changes in the Gini coefficient is proposed by Atkinson and Morelli (2014). They note that "a Gini coefficient of $G$ percent means that, if we take any two households from the population at random, the expected difference is $2 \mathrm{G}$ percent of the mean." Thus, the reduction in household income inequality in Latin America and the Caribbean implies that the expected income difference between two households picked at random in the region has gone down by $10 \%$ of the mean income, from 111.2 to $100.6 \%$.

The reduction of inequality in Latin America and the Caribbean was not only unprecedented in recent history but also distinct when compared with the rest of the world (Lustig et al. 2013). For a global comparison of consumption inequality statistics, Alvaredo and Gasparini (2015) compiled data for as many as 130 countries for the period 1980-2010. ${ }^{3}$ The trends confirm the sharp inequality reduction in Latin America and the Caribbean and the contrast with developing countries in other regions, where inequality fell from an average of 40.6 Gini points to 39.4 points.

\footnotetext{
${ }^{2}$ The Gini coefficient is a measure of statistical dispersion representing the income distribution of a nation's residents. A coefficient of zero expresses perfect equality (every resident has the same income), whereas a coefficient of one (or $100 \%$ ) expresses maximal inequality (one person has all the income, and all others have none).

${ }^{3}$ The dataset was computed mostly from household survey microdata, using the World Bank's PovcalNet online analysis tool (http://iresearch.worldbank.org/PovcalNet/).
} 
Putting numbers in a (recent) historical perspective, Latin America and the Caribbean from the 1970s through the 1990s was nearly 10 points more unequal than Asia, 17.5 points more unequal than the 30 countries in the Organization for Economic Co-operation and Development, and 20.4 points more unequal than Eastern Europe (De Ferranti et al. 2004). During the 2000s, however, the data clearly indicate an inequality convergence, as the less unequal countries experienced larger increases in inequality (Alvaredo and Gasparini 2015).

The decline in income inequality was not driven by a single country or a group of countries. Instead, it was shared across 16 of the 17 countries in which we can consistently measure household income inequality in Latin America and the Caribbean. The only exception was Costa Rica, where inequality increased by 1.7 Gini points. ${ }^{4}$ In spite of the common trends, the reductions are heterogeneous in their magnitude, ranging from 1.4 annual Gini points in Nicaragua (2005-2009) to 0.09 annual Gini points in Colombia (Cord et al. 2014). In general, inequality declined more rapidly among the commodity-exporting countries, which suggests that the spectacular commodity boom may have played a role in the observed inequality dynamics - a hypothesis to which we will return below (Fig. 2).

a) Poverty rate (\$4 a day)

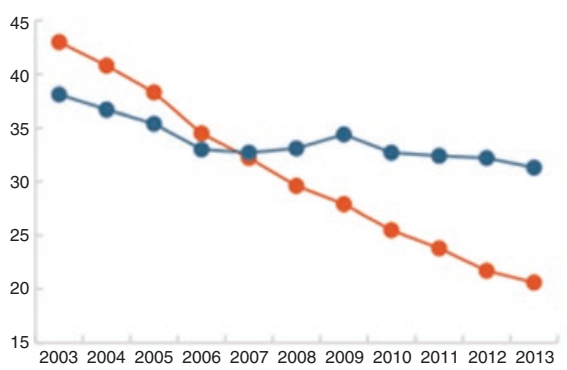

b) Gini coefficient

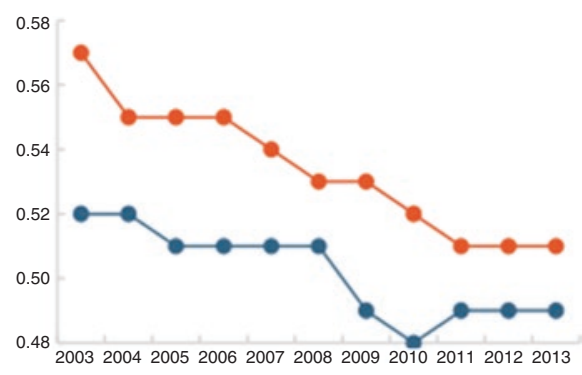

_ Countries without commodity boom —Countries with commodity boom

Fig. 2 Evolution on poverty and inequality in countries with commodity boom and countries without commodity boom, 2003-2013. Source: Based on SEDLAC (CEDLAS and the World Bank). Note: The inequality figures are the weighted average of country-specific Gini coefficients. In order to analyze the same set of countries every year, interpolation was applied when country data were not available for a given year. Commodity-boom countries are those which registered annualized growth in terms of trade above $2 \%$ in the 2003-2013 period (Chile, Bolivia, Colombia, Peru, Ecuador, Brazil, and Argentina). Non-boom countries are the Dominican Republic, Guatemala, Honduras, Mexico, Paraguay, El Salvador, and Uruguay. Due to data limitation, Costa Rica, Panama, and Nicaragua are excluded. Source: Castaneda et al (2015)

\footnotetext{
${ }^{4}$ Despite the change since 2010 in the official methodology to measure income in Costa Rica, there is no evidence of reduction; both the previous and current methodology show an increase.
} 


\subsection{The Role of Labor Income Versus Redistributive Policies}

The fall in labor income inequality was the most important factor that explains the recent downward trend in income inequality in most Latin American and Caribbean countries. There is an intimate relationship in the region between individual earnings inequality and household income inequality (De la Torre et al. 2014, 2015a, b). This is evident in Fig. 3, which shows similar trends in earnings and household income inequality for the region as a whole.

The close relationship between individual earnings and household income inequality is both an artifact and a reality, reflecting at least two important facts. The first regards measurement. The household surveys that we use to measure household income inequality do a good job of tracking earnings, but most likely underestimate the income from sources other than labor. Since nonlabor income tends to be more concentrated in the upper part of the income distribution and labor income is more spread throughout the income distribution (Piketty and Goldhammer 2014), our estimates of household income inequality are likely to be downward biased. Note, however, that in the few countries in which one can correct household income inequality measures in the household surveys using data from top income earners, the inequality levels are

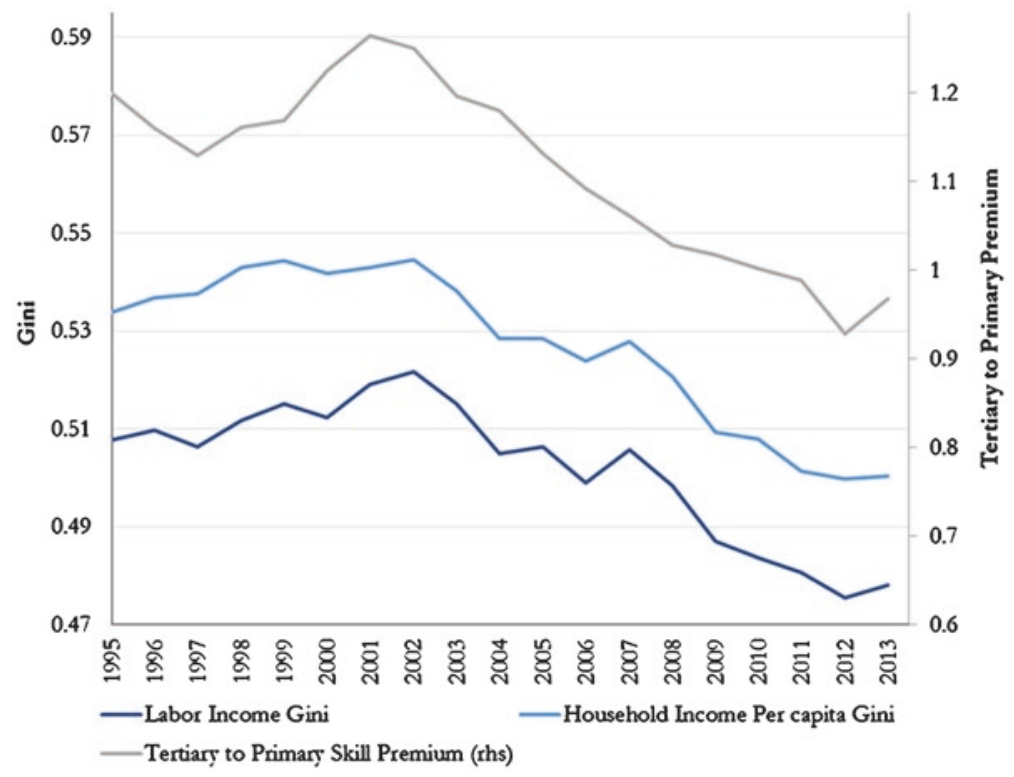

Fig. 3 Labor and total income Gini and the tertiary to primary education wage premium 19952013 (LAC Average). Source: Based on SEDLAC. Notes: The graph plots the simple average across countries of the labor income Gini and household income Gini, and the skill premium of tertiary education relative to primary education. Included are Argentina, Bolivia, Brazil, Chile, Colombia, Costa Rica, the Dominican Republic, Ecuador, Mexico, Panama, Paraguay, Peru, and Uruguay 


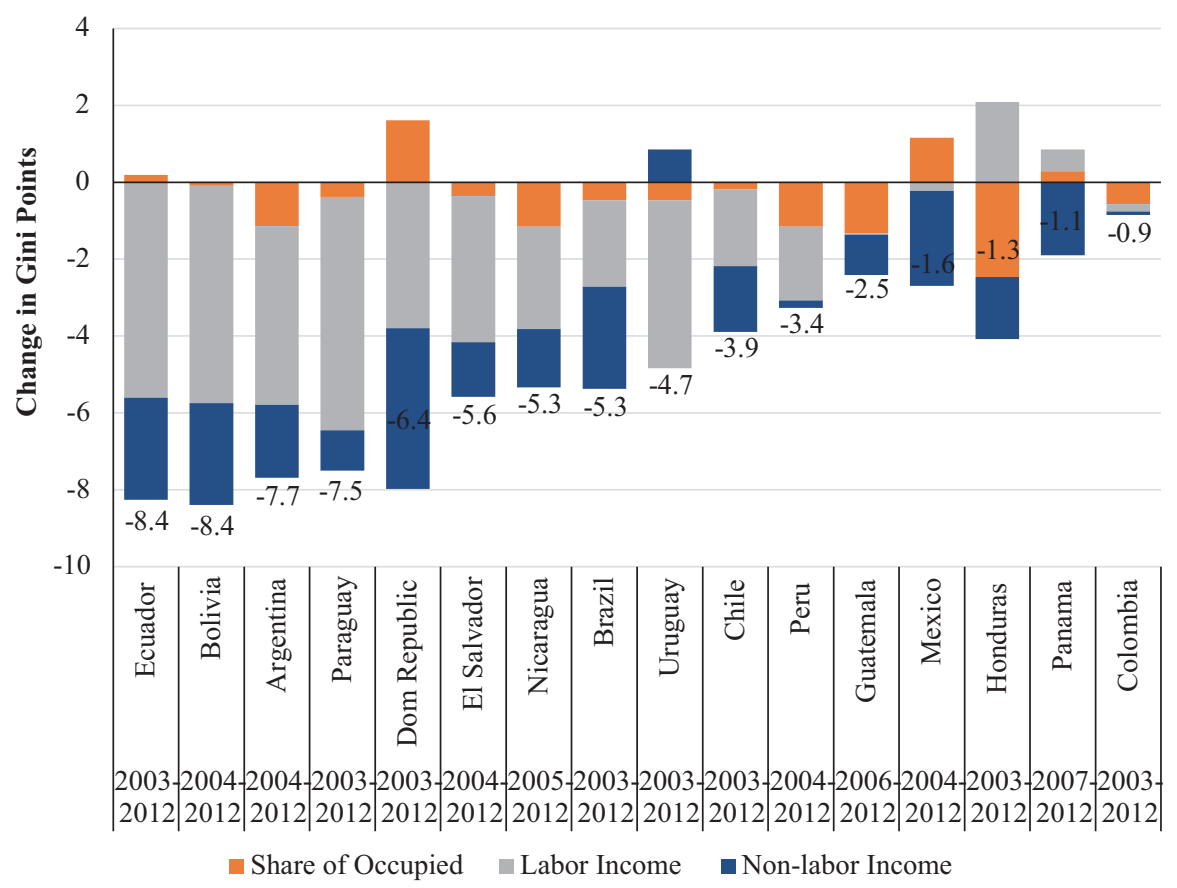

Fig. 4 Decomposition of the evolution of household income inequality in LAC (circa 2003-2012). Source: World Bank (2014). Note: Graph plots the change in the composition of the household income Gini between share of occupied people, labor income, and nonlabor income

altered but not the trends: it is still true that inequality in these countries fell during the 2000s (De la Torre et al. 2014). The second important fact concerns the limited capacity of Latin American states to redistribute income. While these factors might lead to a downward bias in the measurement of nonlabor income, as labor earnings account for the lion share of total income, they are unlikely to challenge the strong association between individual earnings and household income inequality remains.

In Fig. 4 we decompose changes in household income inequality in the evolution of three components: labor earnings, the share of occupied household members, and nonlabor income. A few messages stand out. In all countries considered except Honduras, the evolution of labor earnings contributed to a reduction in inequality. In most of the cases, this contribution was predominant: for Latin America and the Caribbean as a whole, the reduction in annual Gini points was 0.52 , with labor earnings representing 54\% of the overall trend (Azevedo et al. 2014; Cord et al. 2014). Notwithstanding the crucial role of labor incomes - the main asset of the poor-in the reduction of household income inequality, the contribution of nonlabor income cannot be disregarded as minor. In Brazil, in fact, the rapid growth of social programs had a redistributive effect similar in weight to labor income in the annual fall of inequality.

Although the Gini coefficient is a useful summary measure of inequality, other inequality measures are more informative about the potential mechanisms behind labor market developments. A common measure of inequality used by labor economists is 
the log ratio of the 90th to the 10th percentile in the distribution of earnings. This measure can be further decomposed into separate trends for bottom inequality (defined by the $\log (\mathrm{p} 50 / \mathrm{p} 10)$ ratio) and top inequality (approximated by $\log (\mathrm{p} 90 / \mathrm{p} 50)$ ). In most Latin American and Caribbean countries during the 2000s, the reduction of inequality was as important at the top of the earnings distribution as at the bottom (Table 1).

The reduction in inequality during the 2000 s constitutes a unique phenomenon in the recent history of Latin America. Figure 5 shows that there is a turning point in the extent of earning inequality in most countries during the 2000s, the exact moment of the trend reversal depending on each country. In many countries (Argentina, Colombia, Peru) the turning point is around 2002-2003, coinciding with a period of rapid growth and the commodity boom. Note, however, that this rapid decline contrasts with the upward trends of the 1990s, and some signs of stagnation and even raising earnings inequality started around 2012.

\subsection{Decline in the Skill Premium: A Primary Driver of the Fall in Earnings Inequality}

Why did labor earnings contribute so greatly to the reduction of household income inequality? This section shows that the evolution of labor earnings was intimately related to the evolution of the wage premium associated with schooling. More generally, the fall in earnings inequality was associated with a reduction in the returns to workers' skill, for which educational level serves as a proxy.

The evolution of the education premium is always a prime factor behind the evolution of labor earnings inequality. Figure 3 depicts the evolution of the labor income Gini (dark blue line), household income per capita Gini (light blue line), and tertiary versus primary education premium (gray line). As we can see, inequality has shown the same trend as the skill premium-increasing in the 1990s and decreasing throughout the 2000 s.

The reduction in the skill premium and the parallel trends with wage inequality are shared across the vast majority of Latin American and Caribbean countries (Gasparini et al. 2011). Figure 3 shows the tertiary education premium in Argentina, Brazil, Chile, Colombia, Mexico, and Peru. In all those countries except Colombia, the education premium fell rapidly as earnings inequality declined.

The reduction in the returns to education was paralleled by a reduction in the returns to other observable skills. Figure 6 shows the evolution of earnings inequality (as measured by the log ratio p90/p10) and the evolution of earnings inequality net of changes in the composition and returns to labor market observable skills (that is, labor market experience, approximated by the age of workers and education). ${ }^{5}$ Figure 6 plots the $\log$ ratio p90/p10 and the residual $\log$ p90/p10 from a Mincerian type of equation for four countries: Argentina, Brazil, Chile, and Mexico. It is

\footnotetext{
${ }^{5}$ Residual wage inequality is obtained by calculating the percentile ratios from the distribution of the residuals from a flexible Mincer equation with a quadratic term in age, a set of education dummies, and a full set of interaction terms that is estimated year by year.
} 


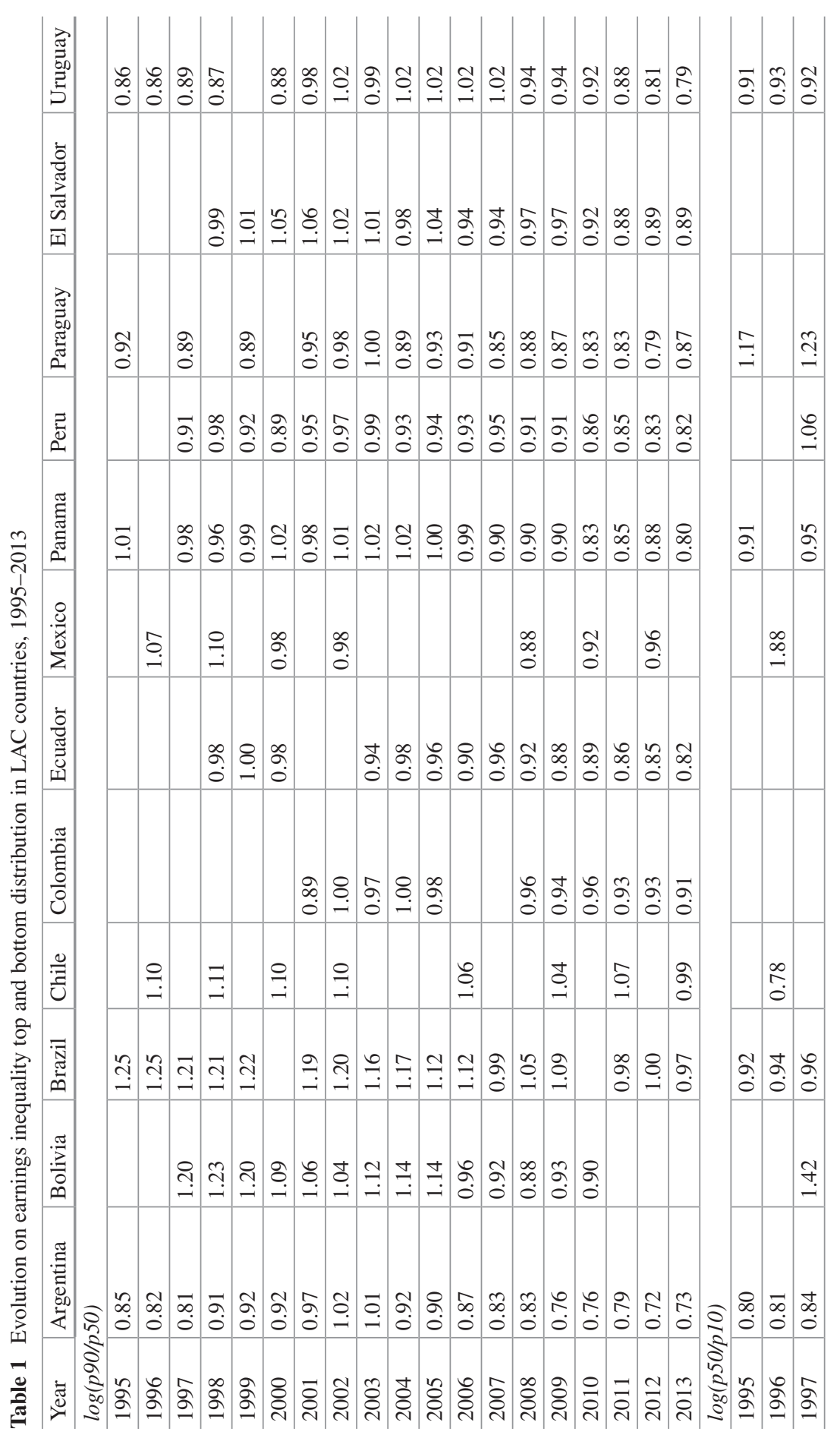




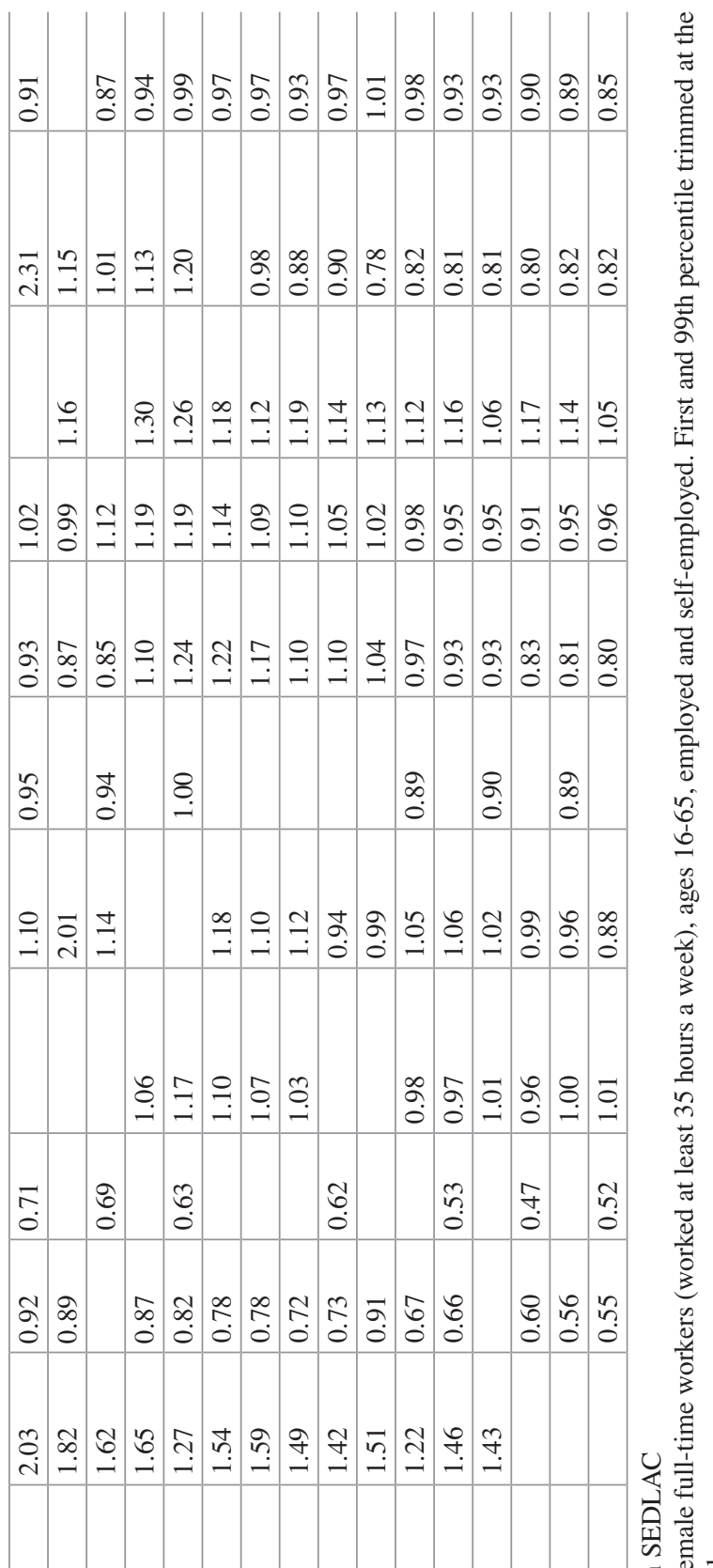

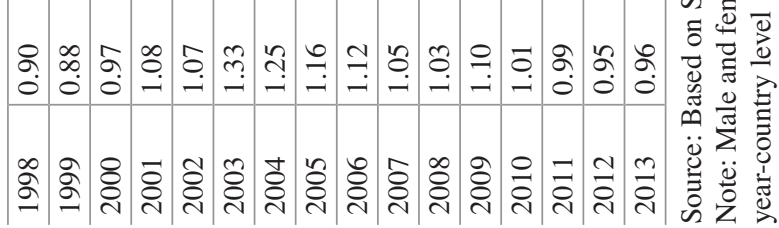




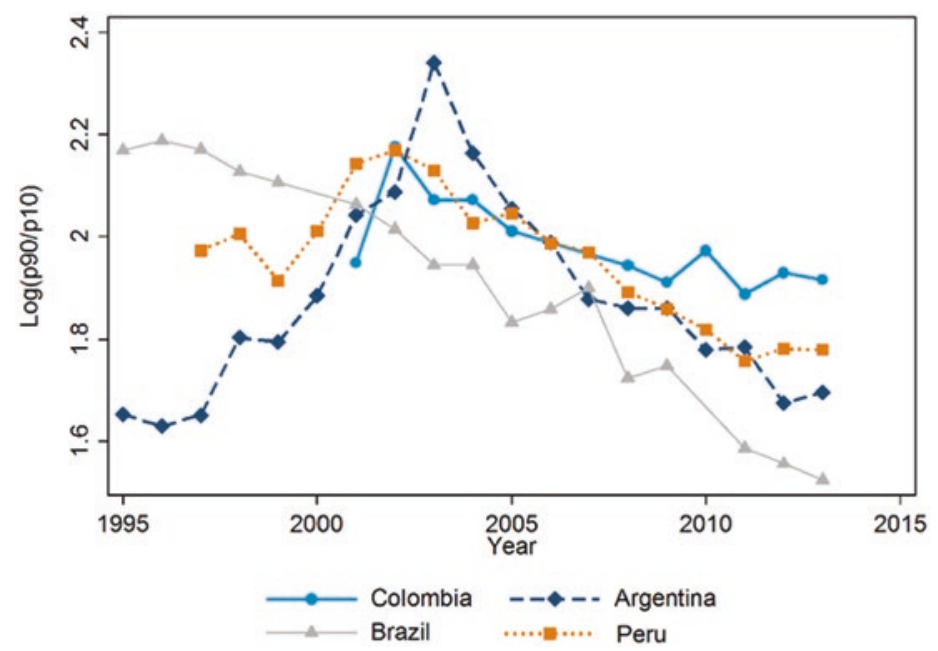

Fig. 5 Evolution of earnings inequality by country 1995-2013. Source: Based on SEDLAC. Note: Male and female full-time workers (worked at least 35 hours a week), ages 16-65, employed and self-employed. First and 99th percentile trimmed at the year-country level
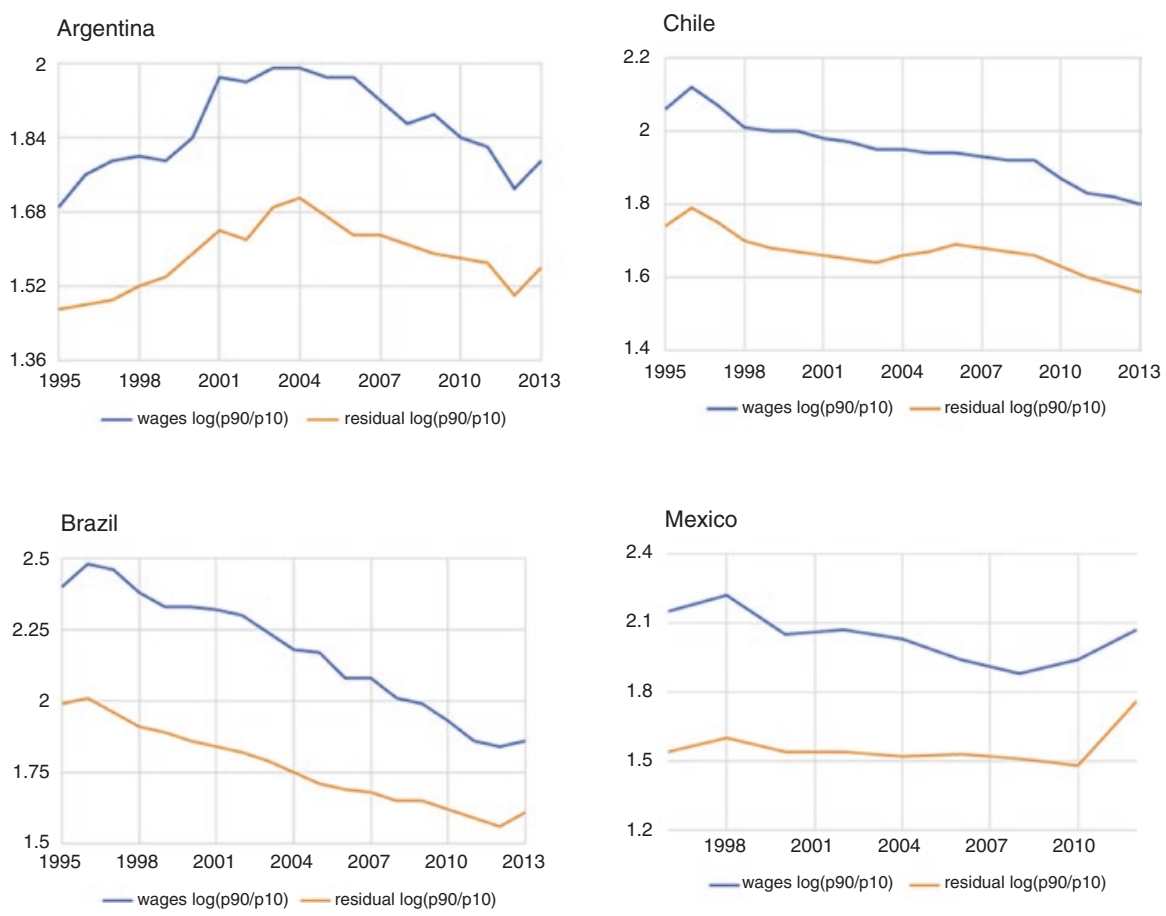

Fig. 6 Evolution of earnings inequality net of changes in the composition and returns to market labor observable skills 1995-2013. Source: Fernández-Sierra, M. and Messina, J. (2015) 
remarkable how similar the trends are between the two curves in all countries. Thus, in the 2000s, Latin America experienced a reduction not only in the returns to education but also in the returns to labor market skills in general.

\section{Why Did the Skill Premium Decrease?}

\subsection{Supply-Side Factors: Rising Numbers of More Educated Workers}

Labor supply developments are a primary determinant of the school premium. In a competitive labor market, if labor demand remains constant, changes in the supply of a particular type of labor (for example, college-educated workers) translate into changes in the education premium. The supply-demand framework has indeed done a remarkably good job of explaining the education premium in the USA (Autor et al. 1998; Katz and Murphy 1992).

At least since the 1990s, all Latin America and Caribbean countries greatly expanded educational attainment. The proportion of the labor force with aboveprimary education increased noticeably (Table 2). The unweighted average share of

Table 2 Evolution of the share of workers with completed primary, secondary, and tertiary

\begin{tabular}{|c|c|c|c|c|c|c|}
\hline Year & $\begin{array}{l}\text { Complete } \\
\text { primary }\end{array}$ & $\begin{array}{l}\text { Diff } \\
\text { primary }\end{array}$ & $\begin{array}{l}\text { Complete } \\
\text { secondary }\end{array}$ & Diff secondary & $\begin{array}{l}\text { Complete } \\
\text { tertiary }\end{array}$ & Diff tertiary \\
\hline \multicolumn{7}{|c|}{ Weighted average } \\
\hline 1990 & 0.09 & & 0.11 & & 0.06 & \\
\hline 1995 & 0.14 & 0.044 & 0.12 & 0.01 & 0.07 & 0.01 \\
\hline 2000 & 0.14 & 0.003 & 0.15 & 0.03 & 0.09 & 0.02 \\
\hline 2005 & 0.13 & -0.005 & 0.19 & 0.04 & 0.10 & 0.02 \\
\hline 2010 & 0.12 & -0.008 & 0.21 & 0.02 & 0.12 & 0.02 \\
\hline 2013 & 0.13 & 0.005 & 0.23 & 0.01 & 0.14 & 0.01 \\
\hline Total diff. & & 0.038 & & 0.11 & & 0.08 \\
\hline \multicolumn{7}{|c|}{ Unweighted average } \\
\hline 1990 & 0.20 & & 0.14 & & 0.07 & \\
\hline 1995 & 0.22 & 0.01 & 0.13 & -0.01 & 0.08 & 0.01 \\
\hline 2000 & 0.18 & -0.04 & 0.15 & 0.02 & 0.09 & 0.01 \\
\hline 2005 & 0.17 & -0.01 & 0.17 & 0.02 & 0.11 & 0.02 \\
\hline 2010 & 0.16 & -0.01 & 0.19 & 0.02 & 0.12 & 0.01 \\
\hline 2013 & 0.16 & 0.00 & 0.20 & 0.01 & 0.14 & 0.02 \\
\hline Total diff. & & -0.04 & & 0.06 & & 0.07 \\
\hline
\end{tabular}

Source: Based on SEDLAC

Note: Estimations used 15 Latin American and Caribbean countries. All female and male workers (salaried, self-employed, and employers) 
the working-age population that completed secondary education in the 15 countries for which data are available rose from 14 to $20 \%$ between 1990 and 2013. This rise is all the more remarkable if we consider the weighted (by population) average, which rose from 11 to $23 \%$ in the same period. ${ }^{6}$

The expansion of tertiary education was equally important. The weighted average share of workers who had completed college almost doubled, rising from $6 \%$ in 1990 to $14 \%$ in 2010 (from 7 to $14 \%$ if we consider the unweighted average). In Brazil and El Salvador, the ranks of working-age individuals with completed secondary and tertiary education more than doubled. In Argentina, Chile, Honduras, and Panama, the share of college graduates doubled. In a third group of countries (Bolivia, Colombia, Costa Rica, the Dominican Republic, Paraguay, and Peru), the registered improvements in educational attainment were significant but more modest (Table 3).

These broad patterns hide substantial country-specific differences in the temporal evolution of educational attainment of the labor force during the 1990s and the 2000s (Table 3). Some countries (Colombia, Costa Rica, and Paraguay) only achieved gains in years of schooling during the 2000s, after a decade of stagnation or (in the case of Paraguay) after a severe deterioration of educational attainment. Others (Brazil and Ecuador) rapidly expanded secondary education in the 1990s, followed by a more intense expansion of tertiary education in the 2000s. But in contrast with the reductions in inequality, which were mostly concentrated during the 2000s, several Latin American and Caribbean countries (notably El Salvador and Uruguay) expanded education more rapidly in the 1990s than in the past decade.

Education is not the only dimension of human capital that can potentially explain wage dynamics. The traditional Mincerian framework highlighted the importance of labor market experience, together with education, in determining wages. The role of experience is largely neglected in the Katz and Murphy (1992) framework, which implicitly assumes that all workers within an educational group are perfect substitutes. This need not be the case, as shown by Card and Lemieux (2001) for the USA and by Manacorda et al. (2010) for Latin America during the 1990s.

Changes in the composition of the labor supply may differ across educational groups. In a rapidly expanding educational system, younger cohorts are likely to be more educated than older cohorts, putting downward pressure on the education premium of workers with little experience in the labor market. These trends may be exacerbated if the rapidly increasing demand for education exerts such pressure on the educational system that a degradation of educational diplomas results (Campos et al. 2014).

Fueled by younger cohorts' increasing demand for education, the rapid expansion of low-quality higher education institutions in Latin America and the Caribbean has sparked concern. One hypothesis put forward, known as the "degraded tertiary"

\footnotetext{
${ }^{6}$ The large difference between the weighted and unweighted measure is mainly due to the spectacular performance of Brazil, where the share of the working-age population with complete secondary education more than doubled during the period, from $13 \%$ in 1990 to $31 \%$ in 2009 (De la Torre et al. 2014).
} 


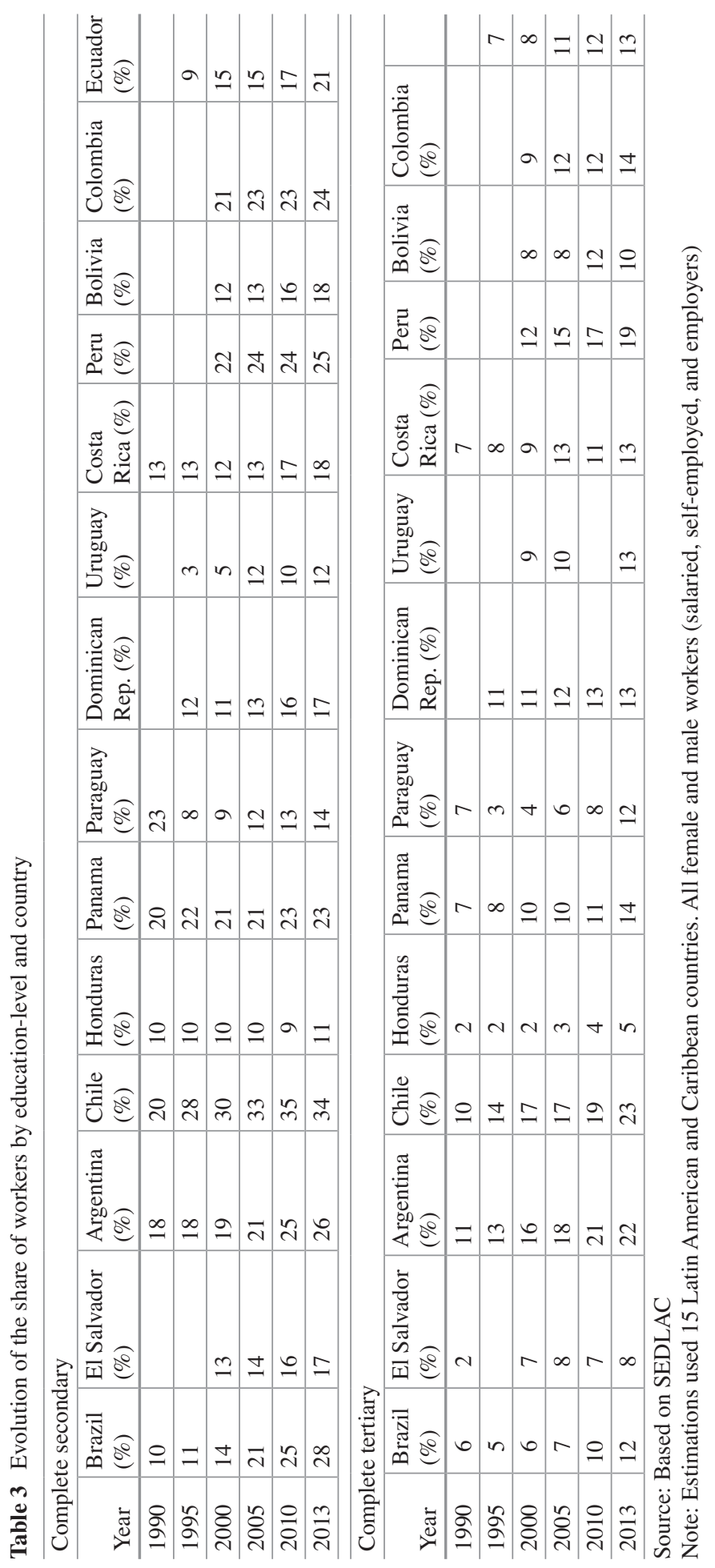


hypothesis (Campos et al. 2014), posits that expansion was accompanied by an increasing dispersion in the quality of education centers, pushing downward the average quality of tertiary education. The so-called garage universities may be eroding the value of educational diplomas, critics note, contributing to a decline in the quality of higher education among labor market entrants and thus to a decline in the returns to education. This hypothesis appears at odds with the empirical evidence, though. First, in several Latin American countries, the education premium has declined more among older cohorts than among younger cohorts. This is explored at length in the cases of Mexico (Campos et al. 2014) and Brazil (Wang 2015). The available evidence is thus more in line with a skill obsolescence hypothesis than with an eroded value of higher education (Campos et al. 2014). Direct evidence for Colombia also argues against this channel of decline in the education premium. In particular, Camacho et al. (2015) show that the value added of new higher education institutions and programs created in the 2000s is very similar to that of the traditional programs. Hence, there is little evidence that the supply of higher education has been degraded.

Another supply-side hypothesis relates to the composition of the supply of educated workers. According to this hypothesis, demographic changes have resulted in an increase in the share of older workers whose skills become obsolete at a more rapid pace due to the adoption of new technologies, and this effect outweighs the value of work experience. As a result, the wage premium for tertiary education (considering all tertiary educated workers) has fallen on average. Campos et al. (2014) provide some preliminary evidence for Mexico where the real wages of older workers have actually declined in absolute terms. Replicating their analysis for other countries De la Torre et al. $(2015 \mathrm{a}, \mathrm{b})$ find mixed evidence-the relative decline of the wages of older workers doesn't appear to be a widespread phenomenon in LAC. Certainly more research is warranted in this area, however.

Fernández-Sierra and Messina (2015) disentangle the roles of labor market experience and education in explaining the observed skill premium trends. They show that different education premium trends are present across workers with different levels of labor market experience, and such trends are partially explained by relative labor supply dynamics. However, an explanation of a reverse trend-the shift from increasing demand for highly skilled workers in the 1990s to declining demand after 2003 - is needed to fully account for the observed dynamics in the skill premium.

\subsection{Demand-Side Factors: Labor Demand Shifts}

As this chapter has broadly concluded thus far, changes in educational attainment and other human capital dimensions must have played a role in the falling inequality of labor earnings during the 2000s in Latin America and the Caribbean. However, the region's downward inequality trend cannot be explained solely by the increasing number of skilled workers. At the macroeconomic level, the shift in labor income inequality trends between the 1990s and the 2000s is not consistent with the 
constant improvement in the supply of education throughout the period. In other words, the acceleration in the educational attainment of the workforce during the 2000s was not sufficient to explain the rapid decline in the education premium. Rather, the shift in labor earnings inequality coincided more clearly with substantial increases in labor demand during this period.

The 1990s and 2000s were periods of pronounced business-cycle and labordemand trends. After a decade of disappointing growth, the region underwent rapid growth in the 2000s in the wake of rising commodity prices and high growth globally, particularly in China and the Group of 7 (G7) major advanced economies. ${ }^{7}$ The commodity-exporting countries (mostly in South America) ${ }^{8}$ grew substantially faster during the boom years (roughly 2003-2011) than the commodity-importing countries (mostly in Central America and the Caribbean), ${ }^{9}$ which experienced only small trade gains or even losses.

The argument that a reversal in demand trends is needed to account for the shift in wage inequality that occurred in the early 2000s is explored formally by Gasparini et al. (2011), applying Katz and Murphy (1992) to the Latin American data. Their conclusion is that while supply-side forces mattered for inequality dynamics, demand-side determinants - the focus of this section - are key.

Several demand factors have been highlighted in the literature as important drivers of wage inequality, including changes in the industrial structure; technological change (and, more recently, outsourcing); and international trade. These factors (for given (skilled and unskilled) labor supplies) could decrease the wage gap between skilled and unskilled workers, and therefore earnings inequality, by expanding the demand for unskilled labor relative to skilled labor.

Together with underlying supply-side factors discussed in the previous section did labor earnings inequality fall in the 2000 s because of

(a) A specialization pattern (of industrial production) that led to a slower rise in skilled labor demand than supply

(b) Technological change, particularly automation, that was particularly deleterious to skilled as opposed to unskilled occupations, leading firms in the region to become less skill intensive or to move some of the more skill-intensive production and service tasks offshore

(c) Fluctuations in aggregate demand/business cycle that favored unskilled workers relative to skilled ones

This section briefly discusses why neither (a) nor (b) provides a sufficient explanation for the inequality patterns in the 2000s and ultimately focuses on (c).

The specialization story refers to that hypothesis that deindustrialization in the region by eliminating high-skilled manufacturing job sector in favor of low-skilled

\footnotetext{
${ }^{7}$ The G7 countries include Canada, France, Germany, Italy, Japan, the UK, and the USA.

${ }^{8}$ Net commodity-exporting countries in Latin America and the Caribbean include Argentina, Bolivia, Brazil, Chile, Colombia, Ecuador, and Peru.

${ }^{9}$ Net commodity-importing countries in Latin America and the Caribbean include Costa Rica, the Dominican Republic, El Salvador, Guatemala, Honduras, Mexico, Paraguay, and Uruguay.
} 
positions in the construction and service sectors would decrease the skill premium (Gasparini et al. 2011). Under this hypothesis, we should see a decline in the share of the labor force (and a deeper wage compression) in skill-intensive sectors relative to the rest. This fact, however, is not fully consistent with the fact that sectors that in average demand more education grew comparatively more over this period, in contradiction to the premise of a demand shift towards low-skill sectors (De la Torre et al. 2014). Moreover, the implicit assumption that services in LAC are less skill intensive than manufactures is not validated by the data (De la Torre et al. 2015a, b).

Another hypothesis includes skill-biased technological change (Acemoglu 1998; Esquivel and Rodriguez-Lopez 2003). This literature emphasizes that, in developed countries, technological change (particularly automation) is complementary to high-education occupations, a substitute for middle-education occupations, and neither complementary nor a substitute for low-skilled occupations, consistent with a U-shaped change in employment shares across skill levels in the recent decades in the USA. However, in Latin American and Caribbean countries, evidence suggests that employment shares remained fairly constant across skill levels (Messina et al. in press; Silva et al. 2015). In a related strand of the literature, Acemoglu (2003) and Feenstra and Hanson (1997) emphasize the role of outsourcing in the USA, an issue that deserves further research in Latin America and the Caribbean. However, there is some evidence that skill-biased technical change may have actually reduced labor income distribution in LAC through a different channel, i.e., by accelerating skill obsolescence in a way that more than offsets the effects of work experience. The fact that in some LAC countries (e.g., Mexico and Argentina) the wages of older workers fell relative to those of younger workers is consistent with this hypothesis, although the relative impact of this effect on overall labor income distribution is yet to be ascertained (Campos et al. 2014; De La Torre et al. 2015b).

Importantly, in high-income countries, labor demand shifts for skilled versus unskilled workers are typically interpreted as emanating from firm-level changes, that is, as evidence of skill-biased technological change associated with changes in the organization of production (Autor 2007; Autor et al. 1998; Goldin and Katz 2007). However, in Latin America and the Caribbean-where business cycles are much more pronounced and external shocks play a major role in explaining aggregate demand behavior - demand-driven inequality may have a different, more macroeconomic nature. External shocks in the region during the 2000s such as the commodity boom had different effects on commodity-exporting countries (winners from growing demand for commodities) than on commodity-importing countries (losers from higher prices of commodities and import competition) (De la Torre et al. 2015a). This divide between these two types of country groups is also reflected in wage trends, with commodity-exporting countries experiencing faster growth in average wages than commodity-importing countries (Fig. 7). Perhaps even more importantly, labor income inequality fell in both sets of countries but for very different reasons: In commodity exporters, this happened because both skilled and unskilled earnings were rising, but the unskilled component was rising faster in commodity importers, low-skilled workers' earnings were rising, and the skilled 


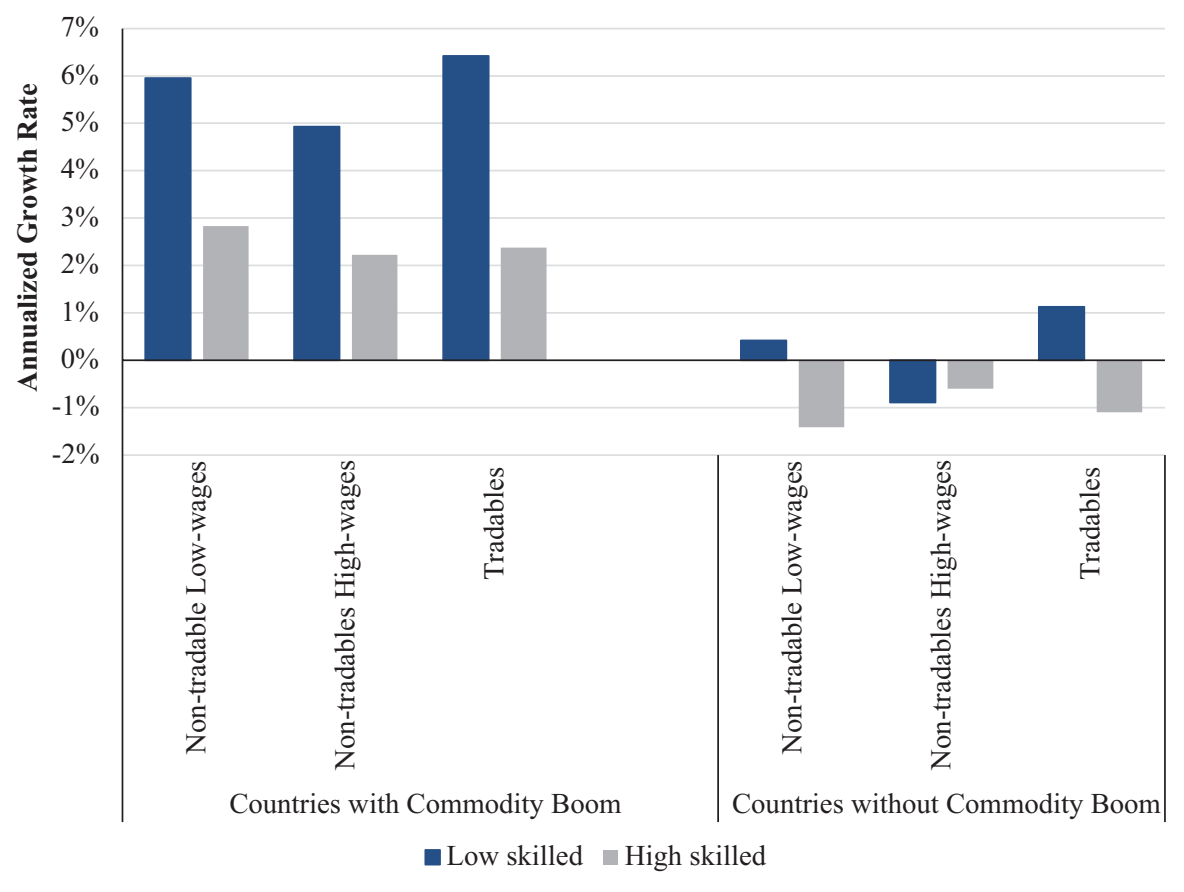

Fig. 7 Wage growth by sector in commodity-boom and no-boom countries in Latin America and the Caribbean, circa 2003-2013. Source: Based on SEDLAC. Notes: The graph plots the change in the simple average wage across countries for each sector and skill level between 2002 and 2011. Countries with commodity boom are Argentina, Brazil, Chile, Colombia, Ecuador, and Peru; countries without commodity boom are Mexico, Peru, and Uruguay. Tradables sector includes primary and manufacturing; non-tradable low-wage sector includes construction, hotels and restaurants, public administration, wholesale retail, and private households; non-tradable high-wage sector includes all other services. Low skilled is up to incomplete secondary education and high skilled completes secondary or more

workers' earnings were falling (Fig. 7). This difference and its role behind the unexpected decline in the labor income Gini throughout the region is a topic that deserves further research. ${ }^{10}$

Moreover, beyond the commodity boom and China's economic rise in the 2000s, other external shocks shifted demand in the 1990s in Latin America and the Caribbean, including the important change in trade patterns due to trade liberalization. ${ }^{11}$ Most trade models suggest that changes in output prices drive changes in wage inequality. In fact, the links between product prices and factor returns are a key element of general equilibrium trade models. Interest in these links was

\footnotetext{
${ }^{10}$ For a comprehensive discussion, see De la Torre et al. (2015a, b).

${ }^{11}$ Importantly, other factors linked with globalization have been shown to contribute to inequality trends. These include outsourcing (Acemoglu et al. 2015; Feenstra and Hanson 1997); exchange rate movements (Verhoogen 2008); and the rise of China (Chiquiar and Ramos-Francia 2008; Dussel Peters and Gallagher 2013).
} 
heightened by the "trade and wages" debate, where lower prices of unskilled labor-intensive products were advanced as one explanation for the decline in the relative wage of unskilled workers in advanced, skill-abundant countries (Silva and Bastos 2008). The underlying argument was based on the Stolper-Samuelson theorem, which implies that trade liberalization in countries where unskilled labor is relatively scarce will lead to a fall in both the relative price of unskilled laborintensive imports and the relative return to unskilled labor, and therefore to an increase in wage inequality as well (Falvey et al. 2010). In contrast, in countries where unskilled labor is abundant, the theory would predict that liberalization would lead to a fall in wage inequality.

Hence, these models are less fit to explain why while most trade liberalization occurred in the 1990s, ${ }^{12}$ wage inequality was stagnant or rising in Latin America and the Caribbean during that period (Goldberg and Pavcnik 2007). Moreover, in this strand of the literature, the mechanism by which trade affects labor markets (and thus wage inequality) is through reallocation between sectors, and shifts of employment between sectors in Latin America and the Caribbean were limited in the 2000s when inequality fell. ${ }^{13}$

Recent papers provide several intuitive theoretical mechanisms for such a relationship. Specifically, Acemoglu (2003) presents a model whereby increased international trade induces skill-biased technological change, and therefore trade opening can cause a rise in inequality. Moreover, Halliday et al. (2015) focus on a different factor-firm heterogeneity - and present a trade model whereby variations in the relative price of tradable goods can explain the decline in wage inequality. ${ }^{14}$ Fully uncovering the channels through which aggregate demand has affected income distribution in Latin America and the Caribbean is an important topic for follow-up research.

\section{Conclusion}

This chapter has examined the main trends in labor income inequality in Latin America and the Caribbean and discussed possible driving factors behind the historical facts. It documented three main stylized facts:

\footnotetext{
${ }^{12}$ For example, (a) Mexico's accession to the General Agreement on Tariffs and Trade (GATT) (later the World Trade Organization [WTO]) in 1986 (Revenga 1997); and (b) Brazil's trade liberalization from 1988 to 1995 (Gonzaga et al. 2006).

${ }^{13}$ On labor mobility costs across sectors, see Artuc et al. (2015), Hollweg et al. (2014), and the references therein.

${ }^{14}$ In addition to market forces that affect supply and demand of skilled and unskilled workers, institutional factors such as the minimum wage and unionization can also come into play. Barros et al. (2010) argue that, in Brazil, minimum-wage policy played an important role in inequality reduction. In a linked paper, Ferreira et al. (2014) find that although the minimum wage contributed significantly to inequality reduction, factors such as the decrease in wage gaps between urban and rural residents, formal and informal workers, and men and women (which could have also been influenced by the minimum-wage policy indirectly) were also key. Papers on the role of unionization in Latin America and the Caribbean are rarer. An important exception is Gasparini and Cruces (2010), which argues that, in Argentina, empowerment of unions contributed to wage compression within firms.
} 
- After decades of growing or stagnant inequality, household income inequality throughout the region fell substantially during the 2000s, a remarkable break from the upward trajectory of household income inequality during the 1980s and 1990s.

- Such trends in household income inequality were driven predominantly by the behavior of Latin American labor markets.

- The reduction in labor income inequality was, in turn, largely driven by changes in the skill premium (as measured by the wage returns to tertiary versus primary education), which again followed a path that broadly mirrored-over the entire period - that of labor income inequality.

The chapter also presented evidence that the region's rising inequality of labor market earnings in the 1990s and falling inequality in the 2000s cannot be explained solely by supply-side factors such as the increasing number of more educated workers. Providing evidence in this direction is the region's experience during the 1990s and early 2000s, when household and labor income distribution worsened but the rates of increase in the supply of education were very similar (and even higher) than during the boom years (2003-2011), when income inequality declined. The decline in the quality of supply (lower quality of tertiary education among new entrants to the labor force) and faster skill obsolescence due to changes in demand provide complementary explanations, but there is relatively little evidence on these factors.

In search of an explanation for the reversal in inequality trends, this chapter suggests that more research is needed but that we are not completely in the dark. It argues that supply-only stories are not sufficient to explain the skill premium trajectory and that demand seems to have played a significant role (not least because it can be one of the common factors behind the unexpected decline in the labor income Gini throughout the region). Fully uncovering the channels through which demand operated is, however, a difficult task and an important topic for follow-up research.

Acknowledgements We are grateful to Alejandra Martinez who provided excellent research assistance, Daniel Valderrama who provided very useful inputs, and participants at the regional conference "Latin American Inequality in the Long Run" in Buenos Aires, December 3-5, 2014, for helpful comments. We remain responsible for any errors. The views expressed in this chapter are those of the authors and should not be attributed to the institutions they are affiliated with.

Open Access This chapter is distributed under the terms of the Creative Commons Attribution 4.0 International License (http://creativecommons.org/licenses/by/4.0/), which permits use, duplication, adaptation, distribution and reproduction in any medium or format, as long as you give appropriate credit to the original author(s) and the source, a link is provided to the Creative Commons license and indicate if changes were made.

The images or other third party material in this chapter are included in the work's Creative Commons license, unless indicated otherwise in the credit line; if such material is not included in the work's Creative Commons license and the respective action is not permitted by statutory regulation, users will need to obtain permission from the license holder to duplicate, adapt or reproduce the material.

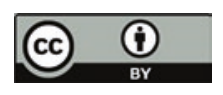




\section{References}

Acemoglu, D. (1998). Why do new technologies complement skills? Directed technical change and wage inequality. Quarterly Journal of Economics, 113(4), 1055-1089.

Acemoglu, D. (2003). Patterns of skill premia. Review of Economic Studies, 70(2), 199-230.

Acemoglu, D., Gancia, G., \& Zilibotti, F. (2015). Offshoring and directed technical change. American Economic Journal: Macroeconomics, 7(3), 84-122.

Alvaredo, F., \& Gasparini, L. (2015). Recent trends in inequality and poverty in developing countries. In A. B. Atkinson \& F. Bourguignon (Eds.), Handbook of income distribution (Vol. 2, pp. 697-805). Amsterdam: Elsevier.

Artuc, E., Lederman, D., \& Porto, G. (2015). A mapping of labor mobility costs in the developing world. Journal of International Economics, 2015, 28-41.

Autor, D. (2007). Structural demand shifts and potential labor supply responses in the new century. In Paper prepared for the Federal Reserve Bank of Boston conference on "Labor Supply in the New Century," June 19-20.

Autor, D., Katz, L., \& Krueger, A. (1998). Computing inequality: Have computers changed the labor market? Quarterly Journal of Economics, 113(4), 1169-1214.

Atkinson, A. B. and Morelli, S. (2014). "Chartbook of Economic Inequality.” ECINEQ WP 324.

Azevedo, J., Inchauste, G., \& Sanfelice, V. (2013). Decomposing the recent inequality decline in Latin America. Policy Research Working Paper 6715. Washington, DC: World Bank.

Azevedo, J., Inchauste, G., \& Sanfelice, V. (2014). Understanding changes in poverty. Directions in development series. Washington, DC: World Bank.

Barros, R., De Carvalho, M., Franco, S., \& Mendonca, R. (2010). Markets, the state and the dynamics of inequality in Brazil. In L. F. Lopez-Calva \& N. Lustig (Eds.), Declining inequality in Latin America: A decade of progress? Washington, DC: Brookings Institution and UNDP.

Bastos, P., \& Silva, J. (2008). The wage and unemployment impacts of trade adjustment. In: D. Greenaway, R. Upward, \& P. W. Wright (Eds.), Globalization and labour market adjustment. New York: Palgrave Macmillan.

Camacho, A., Messina, J., \& Uribe, J. (2015). Heterogeneous returns to higher education: 'Bad' Programs or 'Bad' Students? Unpublished manuscript. Washington, DC: World Bank. Background Paper for the Chief Economist Office study on Wage Inequality in LAC.

Campos, R., Lopez-Calva, L. F., \& Lustig, N. (2014). Declining wages for college-educated workers in Mexico: Degraded tertiary or skills obsolescence? Unpublished manuscript. Washington, DC: World Bank. Background paper for the Chief Economist Office study on Wage Inequality in LAC.

Card, D., \& Lemieux, T. (2001). Can falling supply explain the rising return to college for younger men? A cohort-based analysis. Quarterly Journal of Economics, 116(2), 705-746.

Castañeda, A., Del Carmen Hasbun, G. E., Lucchetti, L. R., Moreno Herrera, L. L., De Gouvea Scot De Arruda, T., Sousa, L. D. C., et al. (2015). Working to end poverty in Latin America and the Caribbean: Workers, jobs, and wages. Washington, DC: World Bank Group.

Chiquiar, D., \& Ramos-Francia, M. (2008). A note on Mexico and U.S. manufacturing industries' long-term relationship. Working paper 2008-08, Banco de México, Mexico City.

Cord, L. J., Cabanillas, O. B., Lucchetti, L., Rodríguez-Castelán, C., Sousa, L. D., \& Valderrama, D. (2014). Inequality stagnation in Latin America in the aftermath of the global financial crisis. Policy Research Working Paper 7146. Washington, DC: World Bank.

De Ferranti, D., Perry, G., Ferreira, F., \& Waltin, M. (2004). Inequality in Latin America: Breaking with history? Washington, DC: World Bank.

De la Torre, A., Beylis, G., \& Ize, A. (2015a, October). Jobs, wages and the Latin American slowdown. Latin America and the Caribbean semiannual report. Washington, DC: World Bank.

De la Torre, A., Lederman, D., \& Silva, J. (2015b). The inequality story in LAC: Searching for an explanation. Presentation at inequality conference, Bank of Spain.

De la Torre, A., Yeyati, E., Beylis, G., Didier, T., Rodríguez-Castelán, C., \& Schmukler, S. (2014). Inequality in a lower growth Latin America. Latin America and the Caribbean Semiannual Report (October). Washington, DC: World Bank. 
Dussel Peters, E., \& Gallagher, K. P. (2013). NAFTA's uninvited guest: China and the disintegration of North American trade. CEPAL Review, 110(August), 83-108.

Esquivel, G., \& Rodriguez-Lopez, J. A. (2003). Technology, trade, and wage inequality in Mexico before and after NAFTA. Journal of Development Economics, 72(2), 543-565.

Falvey, R., Greenaway, D., \& Silva, J. (2010). Trade liberalization and human capital adjustment. Journal of International Economics, 81(2), 230-239.

Feenstra, R. C., \& Hanson, G. H. (1997). Foreign direct investment and relative wages: Evidence from Mexico's maquiladoras. Journal of International Economics, 42(3-4), 371-393.

Fernández-Sierra, M., \& Messina, J. (2015). The role of human capital in the trend reversal of wage inequality in Latin America. Unpublished manuscript. Washington, DC: World Bank. Background paper for the Chief Economist Office study on Wage Inequality in LAC.

Ferreira, F., Firpo, S., \& Messina, J. (2014). A more level playing field? Explaining the decline in earnings inequality in Brazil, 1995-2012. IRIBA (International Research Initiative on Brazil and Africa) Working Paper 12, University of Manchester, United Kingdom. Background paper for the Chief Economist Office study on Wage Inequality in LAC.

Gasparini, L., \& Cruces, G. (2010). A distribution in motion: The case of Argentina. In L. F. LópezCalva \& N. Lustig (Eds.), Declining Inequality in Latin America: A decade of progress (pp. 100-133). Washington, DC: Brookings Institution and United Nations Development Programme (UNDP).

Gasparini, L., Galiani, S., Cruces, G., \& Acosta, P. (2011). Educational Upgrading and Returns to Skills in Latin America: Evidence from a Supply-demand Framework, 1990-2010. Policy Research Working Paper 5921. Washington, DC: World Bank.

Gasparini, L., \& Lustig, N. (2011). The rise and fall of income inequality in Latin America. Working Paper 1110. Tulane University, New Orleans.

Goldberg, P., \& Pavcnik, N. (2007). Distributional effects of globalization in developing countries. Journal of Economic Literature, 45(1), 39-82.

Goldin, C., \& Katz, L. F. (2007). The race between education and technology: The evolution of U.S. educational wage differentials, 1890-2005. Working Paper 12984. Cambridge, MA: National Bureau for Economic Research.

Gonzaga, G., Menezes Filho, N., \& Terra, C. (2006). Trade liberalization and the evolution of skill earnings differentials in Brazil. Journal of International Economics, 68(2), 345-367.

Halliday, T., Lederman, D., \& Robertson, R. (2015). Tracking wage inequality trends with prices and different trade models: Evidence from Mexico. Unpublished manuscript. Washington, DC: World Bank. Background paper for the Chief Economist Office study on Wage Inequality in LAC.

Hollweg, C. H., Lederman, D., \& Mitra, D. (2014). Structural reforms and labor market outcomes: International panel data evidence. Policy Research Working Paper Series 7122. The World Bank.

Katz, L., \& Murphy, K. (1992). Changes in relative wages, 1963-1987: Supply and demand factors. Quarterly Journal of Economics, 107(1), 35-78.

López-Calva, L., \& Lustig, N. (Eds.). (2010). Declining inequality in Latin America: A decade of progress? Washington, DC: Brookings Institution and United Nations Development Programme (UNDP).

Lustig, N., López-Calva, L., \& Ortiz-Juarez, E. (2013). Declining inequality in Latin America in the 2000s: The cases of Argentina, Brazil, and Mexico. World Development, 44, 129-141.

Manacorda, M., Sánchez-Páramo, C., \& Schady, N. (2010). Changes in returns to education in Latin America: The role of demand and supply of skills. Industrial \& Labor Relations Review, 63(2), 307-326.

Messina, J., Pica, G., \& Oviedo, A. M. (in press). From occupations to skills: Changes in skill demand in LAC. Unpublished manuscript. Washington, DC: World Bank. Background paper for the World Bank LAC Chief Economist Office study on Wage Inequality. Piketty 2014.

Piketty, T., \& Goldhammer, A. (2014, March). Capital in the twenty-first century. Print. Harvard University Press.

Revenga, A. (1997). Employment and wage effects of trade liberalization: The case of Mexican manufacturing. Journal of Labour Economics, 15(3), 20-43. 
Rodríguez-Castelán, C., López-Calva, L. F., Lustig, N., \& Valderrama, D. (2016, August 15). Understanding the dynamics of labor income inequality in Latin America. World Bank Policy Research Working Paper No. 7795.

Silva, J., Almeida, R., \& Strokova, V. (2015). Sustaining wage and employment gains in Brazil: A skills and jobs agenda. Washington, DC: World Bank. Directions in development series.

Verhoogen, E. A. (2008). Trade, quality upgrading, and wage inequality in the Mexican manufacturing sector. Quarterly Journal of Economics, 123(2), 489-530.

Wang, Y. (2015). Decomposing the changes in male wage distribution in Brazil. Unpublished manuscript. Washington, DC: World Bank. Background paper for the World Bank LAC Chief Economist Office study on Wage Inequality.

Williamson, J. G. (2015). Latin American inequality: Colonial origins, commodity booms, or a missed 20th century leveling? Working Paper 20915. Cambridge, MA: National Bureau of Economic Research.

World Bank. (2011a). A break with history: Fifteen years of inequality reduction in Latin America. LCSPP Poverty and Labor Brief No. 2. Washington, DC: World Bank.

World Bank. (2011b). On the edge of uncertainty: Poverty reduction in Latin America and the Caribbean during the great recession and beyond. LCSPP Poverty and Labor Brief No. 3. Washington, DC: World Bank.

World Bank. (2014). Social gains in the balance-A fiscal policy challenge for Latin America and the Caribbean. LAC Poverty and Labor Brief (February). Washington, DC: World Bank.

World Bank. (2015). Working to end poverty in Latin America and the Caribbean-workers, jobs and wages. LAC Poverty and Labor Brief (June). Washington, DC: World Bank.

Augusto de la is the Chief Economist for Latin American and the Caribbean at the World Bank. Prior to this, he has held the positions of Senior Advisor in the Financial Systems Department and Senior Financial Sector Advisor, both in the Latin America and the Caribbean region. He has published extensively on a broad range of macroeconomic and financial development topics. He is a member of the Carnegie Network of Economic Reformers. He earned his Ph.D. and M.A. in Economics at the University of Notre Dame and holds a Bachelor's degree in Philosophy from the Catholic University of Ecuador.

Julián Messina is lead research economist at the research department of the Inter-American Development Bank. Previously, he worked for the World Bank and the European Central Bank. He has taught at the Universities of Barcelona GSE, Georgetown, Girona, Frankfurt, and Mainz. He is the author of two flagship reports of the Latin America region at the World Bank, and his research has been extensively published in leading academic journals. He has experience advising governments in Latin America, Europe, and Asia. He obtained his Ph.D. in Economics at the European University Institute.

Joana Silva is a Senior Economist at the Office of the Chief Economist for Latin America and the Caribbean Region of the World Bank. She has expertise in labor economics, international trade, poverty and inequality, and policy evaluation. Her research has been published in academic journals, including the Journal of International Economics, Economics Letters, Review of International Economics, and Review of World Economics. She authored three books, including a World Bank flagship report. She is currently leading a regional research report on wage inequality in Latin America and a number of impact evaluations. Before joining the Bank, Joana worked for the Globalization and Economic Policy Research Center and taught at the University of Nottingham. She holds a Ph.D. in Economics from the University of Nottingham. 